\title{
Wplyw antropopresji na przemiany środowiskowe w dolinie Warty w Poznaniu
}

\author{
Environmental changes in the Warta valley within the Poznań area connected \\ with antropopressure
}

\begin{abstract}
Alfred Kaniecki
Instytut Geografii Fizycznej i Ksztaltowania Środowiska Przyrodniczego, Uniwersytet im. Adama Mickiewicza w Poznaniu, Poznań, alkan@amu.edu.pl
\end{abstract}

Zarys treści: $\mathrm{W}$ pracy podjęto próbę rekonstrukcji pierwotnych warunków środowiskowych, tj. sprzed okresu budowy grodu i miasta, a głównie hydrologicznych i hipsometrycznych warunków, oraz określono, jak wpłynęły one na pierwotny układ miasta oraz jak zmieniały się w okresie późniejszym. Najstarsze osadnictwo w Poznaniu na Ostrowie Tumskim rozwijało się na terasie zalewowej. Analiza archeologicznych i geologicznych materiałów z obszaru Poznania dostarczyła informacji o miąższości utworów nasypowych. Pozwoliło to następnie zrekonstruować przedosadniczą powierzchnię terenu, dawne stosunki wodne i wilgotnościowe i szybkość narastania różnego typu warstw akumulowanych w obrębie obszaru miejskiego. Analiza najstarszych map Poznania umożliwiła rekonstrukcję sieci hydrograficznej w dolinie Warty i jej zmiany. Z kolei analizy tekstów źródłowych z XII-XVII w. pozwoliły na odtworzenie zmian rzeźby terenu przyległego do Ostrowa Tumskiego i lokalizację kilku ostańców wyższych poziomów terasowych w dolinie Warty. Dominacja prac odwodnieniowych w obrębie miasta w ostatnich dwóch wiekach, likwidacja terenów podmokłych i licznych odnóg Warty spowodowały, że Poznań stał się przesuszony, a więc zupełnie inny niż w średniowieczu.

Slowa kluczowe: zmiany środowiskowe, obszar miejski, antropopresja

\begin{abstract}
In this work an attempt was made to reconstruct the initial environmental conditions within the city i.e. prior to its foundation, as well as the hydrological and hypsometric conditions and determine how they affected the origin and later development of the city. The oldest settlement in Poznan in Ostrów Tumski developed on the flood plain. Analysis of the oldest maps of Poznań helps the reconstruction the hydrographic pattern in Warta valley and its changes. Analysis of archeological and geological materials from the Poznan area provided information on the thickness of deposits which helped reconstruct the pre-settlement surface, old water relations and the speed whit which layers accumulated over centuries. Analysis of source texts from the $12^{\text {th }}-17^{\text {th }}$ centuries helped reconstruct changes in the relief of the terrain adjacent Ostrów Tumski and determine a few island mountains of the higher terrace levels in the Warta valley. The dominance of drainage works in the city area in last two centuries, liquidation of wet areas and river pattern made the city terrain very dery - completely different than in the Middle Ages.
\end{abstract}

Key words: environmental changes, city area, antropopressure

\section{Wstęp}

Celem opracowania jest próba przedstawienia, na podstawie faktów $\mathrm{z}$ różnych dziedzin nauki, kierunków przemian środowiska przyrodniczego obszarów dolin rzecznych, wiążących się z działalnością gospodarczą człowieka. W wyniku antropopresji zmianie uległy praktycznie wszystkie elementy fizjograficzne, a więc: układ wód powierzchniowych i ich zasobność, bagna, rzeźba terenu, gleby, szata roślinna i topoklimat. Na obszarze Polski nizinnej w warunkach naturalnych dna dolin rzecznych były na ogół nadmiernie uwilgotnione i trudne do przebycia. Przystosowanie tych terenów do potrzeb człowieka zmieniło całkowicie ich charakter. Po odwodnieniu den dolinnych i uregulowaniu biegu rzek często stawały się obszarami przesuszonymi. Nie stanowiło to jednak 
reguły, bowiem działania człowieka miały charakter wielokierunkowy.

Na ogół nie zastanawiamy się, w jaki sposób i w jakim zakresie obecna powierzchnia obszaru miejskiego uległa przekształceniu i czym różni się ona od powierzchni pierwotnej, na której człowiek nie zaznaczył swej działalności. Nie staramy się również określić, jak pierwotne warunki hipsometryczne czy hydrologiczne wpłynęły na układ przestrzenny zabudowy i na organizację organizmu miejskiego oraz jakim przeobrażeniom ulegały one na różnych etapach rozwoju miasta. Dzisiejszy układ sieci rzecznej na obszarze miejskim różni się od układu sprzed okresu budowy grodu czy miasta, który zachował się tylko w stanie szczątkowym. Podobnie duże zmiany wiążą się z przekształceniem rzeźby obszaru miejskiego w ciągu wieków. Dominowały prace wiążące się z podnoszeniem powierzchni terenu $\mathrm{w}$ celu zaadaptowania go pod zabudowę i ochrony przed wylewami wezbraniowych wód rzecznych, ale natrafiamy również na ślady niwelowania wzniesień. Nasilenie tych prac było zróżnicowane w różnych okresach rozwoju miasta i uzależnione od jego stanu gospodarczego, ale stopniowo doprowadziły one do uformowania się obecnej powierzchni obszaru miejskiego.

Wyraźnie odczuwa się brak literatury ujmującej w całości zagadnienia przekształceń środowiskowych terenów miejskich. Tylko niektóre problemy wchodzące w zakres tych zmian przedstawiono na marginesach innych zagadnień. Nie jest to bowiem temat cieszący się szerszym zainteresowaniem ani geografów czy urbanistów, ani też historyków. W przypadku Poznania zagadnienia zmian środowiskowych obszaru miejskiego przedstawione zostały we wcześniejszych pracach autora (Kaniecki 1993, 2004), opartych głównie na materiałach archiwalnych z dziedziny historii, geologii i kartografii, a ponadto na wynikach badań archeologicznych i geomorfologicznych. Nie wszystkie więc ustalenia lub hipotezy są w pełni wiarygodne, ponieważ nie zostały poparte szczegółowymi badaniami terenowymi. Jednak na dobrą sprawę celowych badań w zakresie zmian środowiskowych na obszarze Poznania jak dotąd nadal nie przeprowadzono.

Informacji na temat dawnej topografii lub układu hydrograficznego w sąsiedztwie Poznania, szczególnie z początkowego okresu istnienia grodu czy miasta, brakuje i dotyczy to nie tylko źródłowych materiałów historycznych. W zasadzie najstarsze dokumenty wiążące się $\mathrm{z}$ istnieniem Poznania na prawym brzegu Warty zupełnie pomijają cechy środowiska przyrodniczego.

\section{Charakterystyka środowiskowa obszaru Poznania}

Do oceny stopnia przekształceń środowiska przyrodniczego w dolinach rzecznych związanych z antropopresją wybrano dolinę Warty w bezpośrednim sąsiedztwie Poznania, a więc w obrębie Przełomowej Doliny Warty, gdzie ten stopień przekształceń był największy i spowodowany różnorodnymi działaniami wynikającymi z potrzeb gospodarczych miasta i jego mieszkańców. W dolinie Warty w Poznaniu działalność człowieka, przystosowująca jej obszar do swoich potrzeb, obejmowała zarówno zmiany rzeźby terenu, wiążące się bądź to z nadsypywaniem niektórych obszarów dla potrzeb osadnictwa, celem zmniejszenia skutków zalewów powodziowych, z budową grobli komunikacyjnych w obrębie doliny Warty, jak i z dostosowaniem istniejącej sieci rzecznej do celów obronnych, gospodarczych i komunikacyjnych. Działania te polegały na wymuszaniu zmian przebiegu koryt Warty, umacnianiu ich brzegów, likwidacji niektórych cieków, tworzenia nowych odnóg dla młynów wodnych, bądź też kanałów i rowów w celu odwodnienia niektórych fragmentów dolin Warty, Bogdanki i Cybiny.

Przełomowa Dolina Warty pod Poznaniem jest formą stosunkowo młodą i jej powstanie wiąże się z odpływem wód roztopowych lądolodu w czasie jego recesji z linii moren czołowych stadiału poznańskiego na linię moren czołowych stadiału pomorskiego, a więc w postglacjale. Holoceńskie zmiany klimatyczne, warunkujące procesy obiegu wody, nie miały już tak wielkiego znaczenia dla kształtowania się spływu wód i morfologii Przełomowej Doliny Warty pod Poznaniem. Obecny spadek Warty od Poznania do Skwierzyny wynosi 0,18\% i 0,14\%o od Skwierzyny do ujścia. Pamiętać jednak należy, że w wyniku XIX- i XX-wiecznych regulacji koryta Warty, polegających na zwężeniu i wyprostowaniu jego przebiegu, nastąpiło znaczne skrócenie biegu rzeki, czego efektem był wzrost jej spadku podłużnego. Dziś dolina Warty nie ma cech terenu nadmiernie uwilgotnionego. W latach normalnych dno doliny stanowią raczej przesuszone łąki, a nie siedliska bagienne. W obrębie Poznania rzędna powierzchni dna doliny wynosi na ogół 54,4-56,0 m n.p.m., tylko na terenach od dawna zasiedlanych (Ostrów Tumski, Chwaliszewo i Grobla) rzędne te wynoszą 57,0-59,0 m n.p.m.

Natomiast terasa II, nadzalewowa, na której rozwinął się Poznań lewobrzeżny po 1253 r., charakteryzuje się rzędnymi od 57,0 do 60,0 m n.p.m. Powierzchnie obu tych najniższych poziomów terasowych podniesiono o około $5 \mathrm{~m}$ w wyniku stosowania nasypów. Na wyższych poziomach terasowych rozwinęły się takie dzielnice jak: Rataje i Komandoria (IV terasa) oraz Wilda, Śródmieście, Naramowice i Starołęka (terasa VII, czyli wysoka). Ponadto zasiedlone zostały obszary wysoczyznowe, po obu stronach doliny Warty, o przeciętnych wysokościach powyżej 80 m n.p.m.

Jednak te tereny wyżej usytuowane zasiedlono dopiero w XIX i XX w. Tak więc Poznań, założony na najniższym poziomie terasowym Warty, wraz z upływem czasu obejmował obszary coraz wyżej położone, aż w XX w. wkroczył na wysoczyznę. Zasiedlanie terenów o różnych wysokościach bezwzględnych wymuszało różne prace wiążące się z ich adaptacją pod zabudowę. Równie wielkim przeobrażeniom jak cechy rzeźby terenu na obszarze Poznania podlegał układ sieci rzecznej, a więc koryt Warty i jej dopływów: Cybiny, Głównej, Bogdanki i Strumienia Junikowskiego. 
Przy odtwarzaniu pierwotnych warunków hydrologicznych, nie zniekształconych antropopresją, pamiętać musimy, jak mało dostępne były wtedy doliny rzek, zarówno dużych, jak i małych. Ta nieprzystępność wiązała się zwłaszcza z podmokłością, występowaniem rozlewisk, starorzeczy i obecnością niekiedy kilku koryt rzeki głównej, która nie stanowiła wtedy stacjonarnego i stabilnego przewodu. Rzeka główna, słabo wcięta w terasę zalewową, często zmieniała bieg w czasie wezbrań.

W zasadzie aż do XIII w. brak ściślejszych wiadomości o hydrograficznej sytuacji w pobliżu miasta Poznania. Z informacji zawartych w źródłach pisanych wynika jednak, że w średniowieczu układ głównych cieków w sąsiedztwie Poznania zbliżony był do tego, jaki przedstawiony jest na planach i widokach miasta z XVII i XVIII w. Tak też bieg Warty i jej odnóg pokazują w swych pracach Łukaszewicz (1838), Callier (1887) i Warschauer (1892), którzy korzystali z planów i materiałów archiwalnych dziś niestety już nie istniejących. Główne koryto Warty dzieliło Poznań średniowieczny od Chwaliszewa, które z kolei od Ostrowa Tumskiego oddzielała odnoga Warty, zwana już w XIII w. Starą Rzeką. Na pewno istniały wtedy dwa ramiona Warty, opływające od wschodu i zachodu wyspę Groblę, z tym że wyspa ta miała inny kształt, niewymuszony umocnieniem brzegów i podniesieniem jej poziomu przez stosowanie nasypów. Ramię od wschodu opływające Groblę na pewno nie skręcało na zachód pod tak ostrym kątem.

W obrębie doliny znacznie więcej było wówczas drobnych strumieni i zbiorników wodnych. Prawdopodobnie Rybaki, osada służebna, położona była na wyspie. Od południa opływała ją odnoga Warty zwana później Kamionką lub Strugą Karmelicką (Karmelitańską), od zachodu odnoga tej strugi - zwana w XVI w. Notecią, a potem Strugą Rybacką - od północy zaś kolejna odnoga Warty, wpadająca do ramienia Warty od zachodu opływającego wyspę Groblę (Kaniecki 1993; ryc. 1).

W miarę wiarygodny układ sieci rzecznej w Poznaniu i jego sąsiedztwie przedstawiony jest dopiero na przekazach kartograficznych z drugiej połowy XVIII w. Wcześniejsze przekazy nie są wiarygodne.

Przedstawiony na XVIII-wiecznych planach układ sieci rzecznej wskutek działalności gospodarczej mieszkańców Poznania miał już wtedy charakter wymuszony. $\mathrm{Na}$ zmianę tego układu składało się nadsypanie o kilka metrów powierzchni wysp śródrzecznych, dawniej zalewowych, tj. przede wszystkim Grobli, a w mniejszym stopniu Chwaliszewa i Ostrowa Tumskiego, i umocnienie brzegów tych wysp. Nadsypywanie powierzchni wyspy Grobli i umacnianie jej brzegów powodowało spychanie koryta Warty w kierunku wschodnim, a następnie wytworzenie bardzo silnej krzywizny. Dopływając do lewobrzeżnego miasta, Warta, w sąsiedztwie mostu Chwaliszewskiego, prawie pod kątem prostym zmieniała swój bieg. Tak wielkie i nienaturalne zakrzywienie koryta rzecznego może być uwarunkowane tylko gospodarczą działalnością człowieka.

W świetle przedstawionych materiałów stwierdzić można, że układ koryta głównego Warty i jego odnóg w sąsiedztwie miasta miał charakter ustalony przynajmniej od średniowiecza, prawie stacjonarny, tym bardziej że brzegi Warty wzmacniano groblami czy też palami, celem uniknięcia przesuwania jej koryta. Bez wątpienia dochodziło do pewnych zmian przebiegu koryta Warty, szczególnie powyżej Poznania, jak chociażby widać to na mapach $z$ lat $1780,1785,1795$, ale odnosi się to do okresu zdziczenia rzeki, kiedy to nie umacniano jej brzegów (Kaniecki 1993; ryc. 2). W XIX i XX w. przeprowadzona została regulacja biegu Warty, wiążąca się głównie ze zwężeniem i wyprostowaniem przebiegu jej koryta. Po-

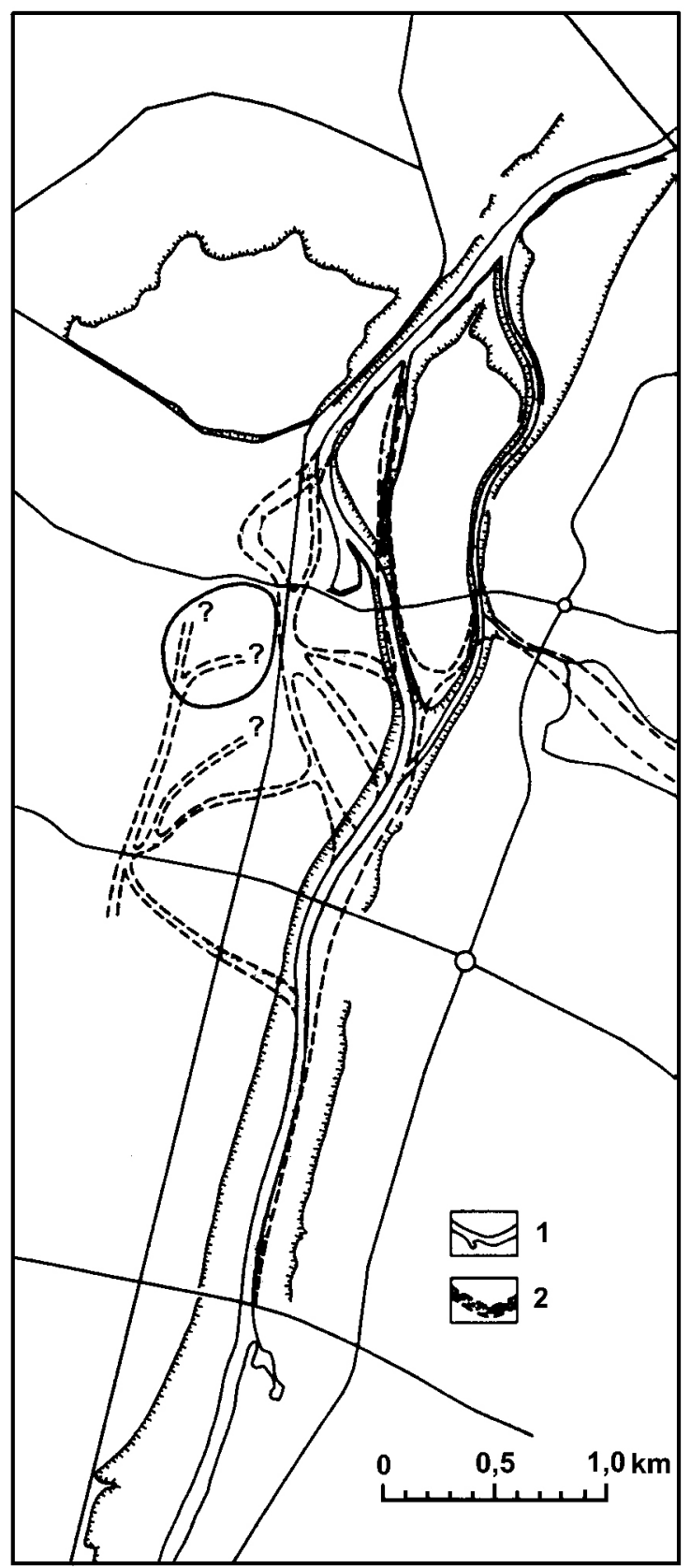

Ryc. 1. Przypuszczalny przebieg dawnego koryta Warty i jej odnóg (2) na tle obecnego układu hydrograficznego (1) i przebiegu głównych ulic

Fig. 1. Probable course of the old Warta channel and its arms (2) against the background of the present hydrographic pattern (1) and the pattern of main streets 


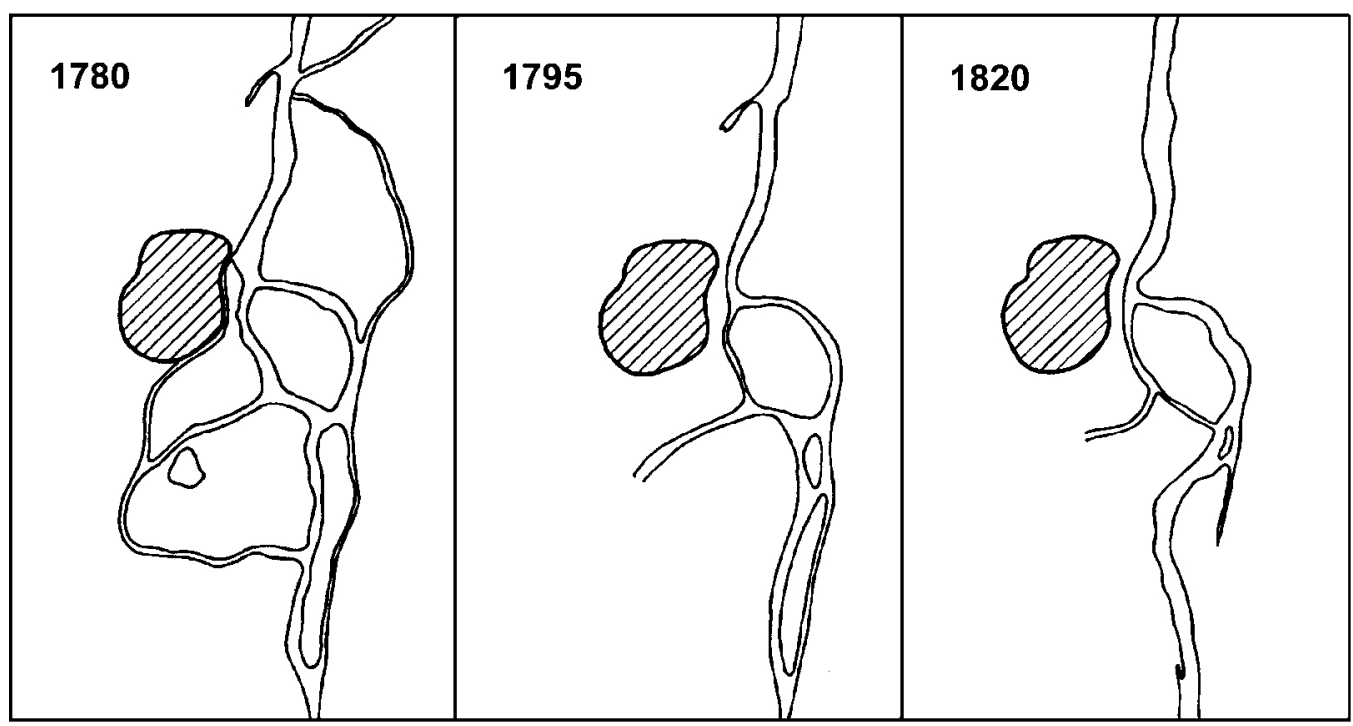

Ryc. 2. Zmiany w przebiegu głównego koryta Warty w świetle przekazów kartograficznych z lat: 1780, 1795 i 1820

Fig. 2. Changes in the course of the main Warta channel in light of maps from 1780, 1795 and 1820

nadto przysypano tereny podmokłe $\mathrm{w}$ dolinie Warty oraz zlikwidowano prawie połowę jej ramion i odnóg, starorzecza i drobne cieki. Największe przemiany środowiska geograficznego w Poznaniu, a w szczególności rzeźby terenu, stosunków wodnych i układu sieci rzecznej, zaszły w obrębie doliny Warty. Dlatego też skupiono się głównie na analizie w jej obrębie tych przemian, zarówno przestrzennych, jak i czasowych.

\section{Przemiany środowiskowe w obrębie doliny Warty w Poznaniu}

W rozwoju każdego miasta można wyróżnić kilka etapów przekształcenia warunków środowiskowych dla potrzeb jego mieszkańców i gospodarki miejskiej. Szczególnie dotyczy to cech rzeźby i układu sieci rzecznej, które stanowią zasadnicze elementy rozwoju strefy miejskiej, jej zabudowy oraz ukazują bariery i ograniczenia w tym rozwoju.

Poznań w pierwszym okresie swego istnienia obejmował obszar wyspy terasy zalewowej, nazywanej dzisiaj Ostrowem Tumskim, a zatem najniższą część doliny Warty. Niskie jego usytuowanie, koryta i odnogi Warty i Cybiny, liczne bagna oraz rozlewiska tworzyły naturalną zaporę obronną, chroniącą podejście pod obwałowany gród. Z kolei sąsiedztwo Warty i Cybiny nie tylko wzmacniało obronność tego miejsca, ale również ułatwiało transport budulca.

Ostrów Tumski, stanowiący jedną z siedzib pierwszych władców Polski, był zagospodarowywany już od przełomu VIII i IX w., a intensywnie od połowy X w. Jednak przykrycie jego powierzchni warstwami kulturowymi, narastającymi w ciągu wieków, sprawia, że odtworzenie jego rzeźby pierwotnej jest stosunkowo trudne. Miąższość gruntów kulturowych zmienia się na obszarze dawnego grodu najczęściej w granicach 5-7 m (ryc. 3) (Kaniecki 1993).
Rekonstrukcję powierzchni pierwotnej, a więc przedosadniczej, należy rozpocząc od zdjęcia z obecnej powierzchni topograficznej doliny gruntów nasypowych, których narastanie wiązało się $\mathrm{z}$ rozwojem osadnictwa w dolinie Warty w Poznaniu. Dla oceny ich zmienności przestrzennej wykorzystano wyniki około pięciu tysięcy wierceń geologicznych, głównie geologiczno-inżynierskich, badawczych i hydrogeologicznych. Charakteryzują się one stosunkowo dobrym rozpoznaniem zmienności warstw przypowierzchniowych, co pozwoliło, łącznie z wynikami badań archeologicznych, określić nie tylko zmienność przestrzenną gruntów nasypowych w dolinach Warty, Bogdanki i Cybiny, ale również odtworzyć rzeźbę przedosadniczej powierzchni terenu, tj. zasięgi dawnych obniżeń i wyniesien, ich rzędne oraz rodzaje gruntów występujących wtedy na powierzchni. Grunty nasypowe składają się przeważnie z piasku wymieszanego z gruzem ceglanym, rzadziej z gruntów gliniastych i organicznych. Największe miąższości gruntów kulturowych, przekraczające wartość $10 \mathrm{~m}$, występują w strefie przyczółków mostowych, dawnych fos oraz na dawnych terenach podmokłych, tj. Groffowych Łąkach, przylegających od wschodu do Wzgórza św. Wojciecha. Najczęściej podnoszono poziom powierzchni terenu wewnątrz grodu lub miasta celem ochrony przed zalewami wód wezbraniowych Warty. $\mathrm{W}$ XX w. np. ziemię z rozbiórki dawnych fortów XIX-wiecznej fortecy wywożono na obszar terasy zalewowej Warty celem podniesienia jej poziomu. Powierzchnia terenu podnosiła się również wskutek narastania warstw osadniczych, około $20-30 \mathrm{~cm}$ na każde pokolenie.

Niecały obszar w obrębie doliny Warty uległ podwyższeniu wskutek stosowania nasypów. Na przykład w obrębie Łęgów Dębińskich część terenu wykorzystywanego przez wieki jako pastwiska, a obecnie na ogródki działkowe (przeważnie o rzędnych ok. 54,5-55,0 m n.p.m.), nie była nadsypywana sztucznie. Jednakże każda powódź zostawiała po sobie serię osadów, nadbudowując w ten sposób poziom terasy zalewowej. Do lat 80. XIX w., 
w rezultacie agradacji (jak wynika z pierwszych, wielkoskalowych map obszaru Poznania, przedstawiających szczegółowo rzeźbę terenu w ujęciu poziomicowym; Rogalanka, Ruszczyńska 1978), poziom terasy zalewowej podniósł się o około $3 \mathrm{~m}$, w odniesieniu do poziomu terasy z X w., wynoszącego wtedy niecałe $52 \mathrm{~m}$ n.p.m., co określono na podstawie badań archeologicznych przeprowadzonych na Ostrowie Tumskim. Tak więc w sytuacji, gdyby terasa II na terenie Poznania nie została podniesiona wskutek nagromadzenia się na niej warstw osadniczych, poziom terasy I, w procesie agradacji, zrównałby się z jej poziomem (Kaniecki 1993).

Poza pracami mającymi na celu podniesienie poziomu terenu wykonywano również prace obniżające jego powierzchnię, czy to w wyniku eksploatacji kopalin ceramicznych (gliny zwałowej, iłów poznańskich i warwowych) czy też piasków i żwirów. Jedne i drugie osady były wykorzystane do budowy nowych dróg. Także ze względów obronnych pewne wyżej położone obszary, a znajdujące się w sąsiedztwie miasta, obniżano oraz zmniejszano stromość skarp doliny Warty. Na niektórych gruntach, poprzednio obniżonych, w wyniku erozji wód Warty i Cybiny oraz eksploatacji surowców ceramicznych, stosowano następnie nasypy, których celem było podniesienie ich poziomu i adaptacja do potrzeb budownictwa czy komunikacji. Przykładem tego typu działań jest obszar położony pomiędzy Śródką a obecnym Jeziorem Maltańskim (ryc. 3).

Zdjęcie warstwy nasypów umożliwiło odtworzenie rzędnych powierzchni pierwotnej w różnych częściach doliny Warty. W obrębie terasy zalewowej, ciągnącej się obecnie wąskim pasem przyległym do koryta Warty, a osiągającej aktualnie rzędną około $53 \mathrm{~m}$ n.p.m., na prawym brzegu Warty stwierdzono miąższości nasypów do $3 \mathrm{~m}$. Z kolei na sztucznej terasie nadzalewowej, na której znajduje się katedra, osiągającej obecnie rzędną około 58 m n.p.m., miąższość gruntów nasypowych waha się najczęściej pomiędzy wartościami 4 i $7 \mathrm{~m}$. Osiągnęła więc rzędną III poziomu terasowego.

Powierzchnię pierwotną, a więc przedosadniczą, odnajdowano w trakcie badań archeologicznych najczęściej na rzędnych od 51,3 do 51,8 m n.p.m. Warstwę powierzchniową stanowiły drobnoziarniste piaski, miejscami zailone, bądź też cienka warstewka osadów zastoiskowych, zalegających na piaskach, wskazując na istnienie płytkich zbiorników wodnych, chyba o charakterze okresowym. Tego typu osady stwierdzono w większości wykonanych wykopów badawczych.

Z zachowanych szczątków botanicznych, reprezentowanych przez: szczaw zwyczajny, szczaw nadmorski, jaskier pstry i turzyce, odnalezionych na poziomie dawnej terasy zalewowej na rzędnej 51,65 m n.p.m., wynika, że obszar ten nieznacznie tylko wystawał ponad poziom wód rzecznych, a rośliny te nadal spotykamy w nisko położonych siedliskach łąkowych nad rzekami. Mniej więcej na tej samej rzędnej stwierdzono obecność warstwy utworzonej z pozostałości roślin bagiennych, szczątków drew-

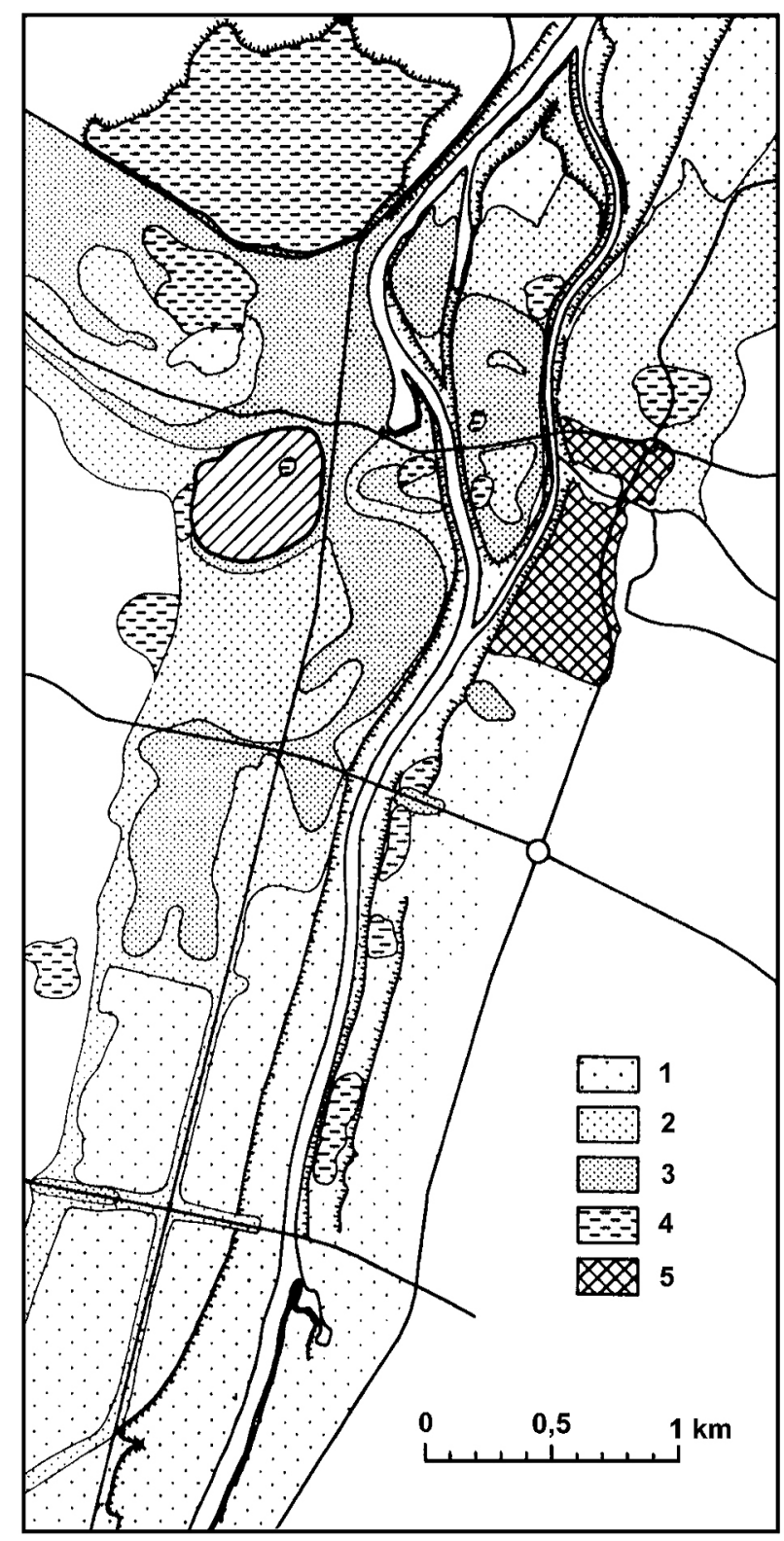

Ryc. 3. Zmiany powierzchni terenu w wyniku prac niwelacyjnych

1 - podniesienie o 0-2 m, 2-podniesienie o 2-5 m, 3-podniesienie > $5 \mathrm{~m}, 4$ - obniżenie powierzchni terenu, 5 - obniżenie, a następnie podniesienie powierzchni terenu

Fig. 3. Changes in the terrain surface following levelling work 1 - raising by $0-2 \mathrm{~m}, 2$ - raising by $2-5 \mathrm{~m}, 3$ - raising $>5 \mathrm{~m}, 4$ - lowering of terrain surface, 5 - lowering and raising of terrain surface

na i sitowia, charakterystycznych dla strefy przybrzeżnej zbiorników wodnych (Niesiołowska i in. 1960). Przyjąć więc można, że przeciętny poziom wód rzecznych wynosił wtedy około 51,5 m n.p.m., a więc był wyraźnie niższy od obecnego, średniego poziomu wody w Warcie $(52,4$ m n.p.m. - Kaniecki 1993). Pozostałości zoologiczne natomiast reprezentowało na tym poziomie kilka gatunków ślimaków i małżów, typowych dla wód stojących lub wolno płynących o mulistym dnie i z bujną roślinnością (Klichowska 1961).

Tak więc w świetle badań archeologicznych i paleobiologicznych stwierdzić można, że część obszaru 
Ostrowa Tumskiego, którą tworzyły łąki nadrzeczne o charakterze łęgowym, była podmokła oraz że występowały w jej obrębie płytkie, okresowe zbiorniki wodne utworzone w czasie wylewów powodziowych Warty.

Niecały jednak teren Ostrowa Tumskiego stanowił przed tysiącem lat płaską terasę zalewową. W trakcie badań archeologicznych odnotowano występowanie obszarów wyżej położonych, na rzędnych około 54-55 m n.p.m., będących pozostałością wyższych poziomów terasowych. $\mathrm{Na}$ jednym $\mathrm{z}$ nich stoi palatium książęce. Obecnie na jego miejscu znajduje się kościół Najświętszej Marii Panny (ryc. 4). Według interpretacji Hensla dawna nazwa Ostrowa Tumskiego - Summum (wzgórze), odnosiła się do połowy X w. (Żak 1959). W czasach późniejszych wzgórze to zanikło $\mathrm{w}$ wyniku nadsypania terenu przyległego poprzez stosowanie nasypów, narastanie warstw kulturowych bądź powodziowych.

Kolejny taki ostaniec wyższego poziomu terasowego, znajdował się w południowej części Ostrowa Tumskiego. W początkach XII w. zbudowano na nim kościół pw. św. Mikołaja, który rozebrany został w 1805 r. Wzgórze to

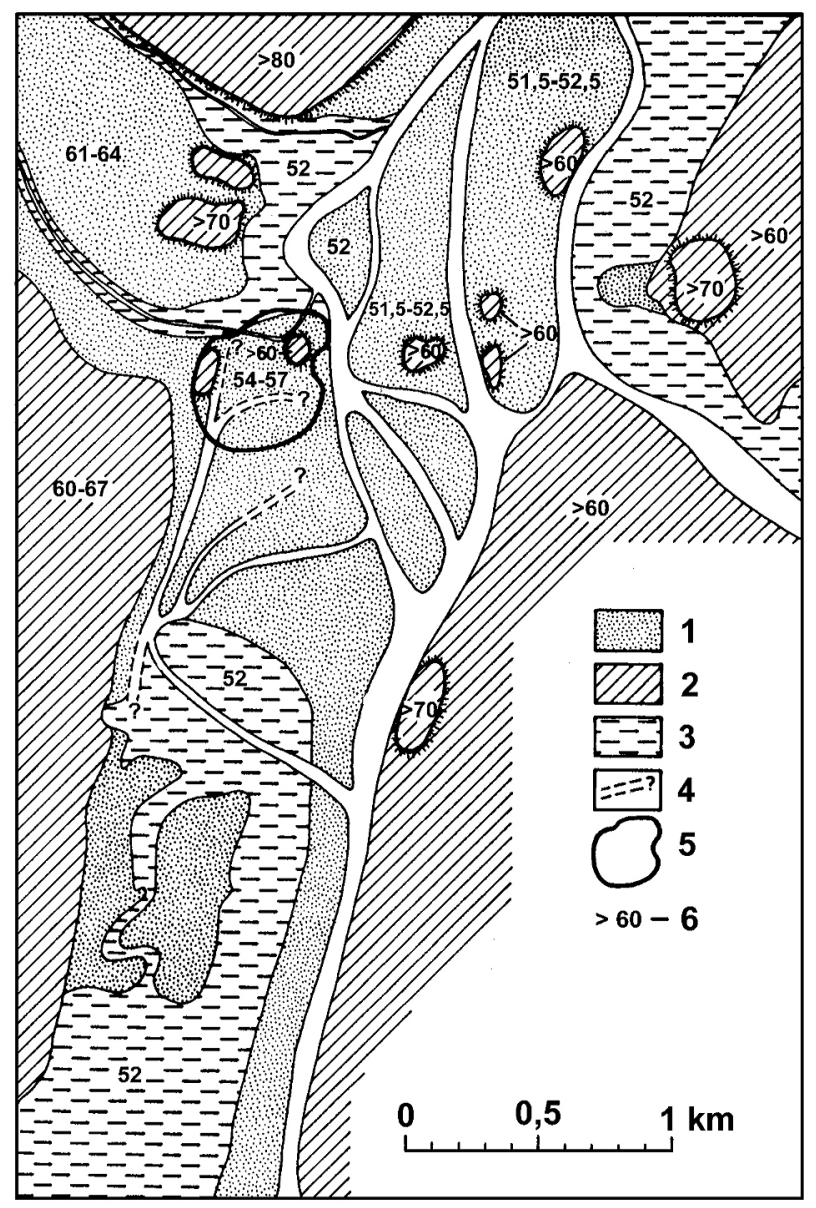

Ryc. 4. Powierzchnia przedosadnicza w dolinie Warty

1 - piaski, 2 - gliny zwałowe, 3 - torfy, 4 - namuły organiczne, 5 - przypuszczalne przebiegi odnóg Warty; wartości liczbowe określają rzędne terenu (m n.p.m.)

Fig. 4. Pre-settlement area in the Warta valley

1 - sands, 2 - boulder clays, 3 - peats, 4 - organic alluvia, 5 - probable courses of Warta arms; numeric values define ordinates of the terrain (m a.s.1.) nosiło nazwę „Wzgórza Kapitulnego” (Mons Capituli), a i kościół nazywano niekiedy „na Wzgórzu Kapitulnym" (in monte Capituli). Stąd też osadę leżącą za tym kościołem nazywano Zagórzem, czyli za Górą Kapitulną. Na przełomie XV i XVI w., kiedy biskupem poznańskim był Jan Lubrański, Wzgórze Kapitulne zbudowane z glin zwałowych, wyeksploatowane zostało dla produkcji cegieł w związku z budową systemu obronnego na Ostrowie Tumskim. Pozostała po nim do dziś tylko nazwa ulicy Zagórze (Nowacki 1959-1964).

Inny ostaniec znajdował się na północ od obecnej linii kolejowej Poznań-Gniezno. Wyznaczony został na podstawie analizy materiałów geologicznych. Glina zwałowa zlodowacenia środkowopolskiego, częściowo przykryta cienką warstwą piasków, występuje na rzędnej 58,0 m n.p.m. (Kaniecki 1993). Jeszcze jeden, stosunkowo niewysoki, stwierdzony został w trakcie badań archeologicznych w centralnej części katedry (Kaniecki 1993).

Kolejnym ostańcem wyższego poziomu terasowego było wzgórze pod Ratajami, prawdopodobnie zniwelowane w XVI i XVII w., ponieważ nie znajdujemy już o nim informacji w późniejszych historycznych przekazach źródłowych, czy też kartograficznych. Ostańcem erozyjnym wyższego poziomu terasowego była Góra Kawalerska, na której zboczu wybudowano klasztor Reformatów. Około 1836 r. wzgórze to zostało splantowane i wybudowano tam fort Prittwitz. W latach międzywojennych zlikwidowano zarówno fort, jak i część wzgórza, a ziemię z jego rozbiórki przewieziono na teren przyszłej elektrociepłowni Garbary i targowicy, położonych w dolinie Warty. Dzisiaj obszar ten wyraźnie wznosi się ponad otaczający teren.

Inny ostaniec znajdował się w północnej części Wyspy Chwaliszewskiej. Ostatni fragment tego ostańca zlikwidowano w latach 20. XX w. Ziemia z tego wzgórza, w ilości około $3000 \mathrm{~m}^{3}$, została zużytkowana na podwyższenie poziomu ulic na Chwaliszewie.

W obrębie Poznania lewobrzeżnego, obwiedzionego murami, znajdowała się tzw. Złota Góra, zwana też Żydowską Górą. Usytuowana była pomiędzy kościółkiem Krwi Pana Jezusa (róg Kramarskiej i Żydowskiej) a klasztorem Dominikanów. Zaznaczona była na niektórych XVIII-wiecznych planach Poznania. Stanowiła również płat wyższego poziomu terasowego. Prawdopodobnie w końcu XVIII w., w ramach prac porządkowych prowadzonych przez Komisję Dobrego Porządku lub po pożarze dzielnicy żydowskiej w 1803 r., wzgórze to splantowano. Szerzej zagadnienia te zostały przedstawione we wcześniej pracy (Kaniecki 1993).

Badania archeologiczne prowadzone na Ostrowie Tumskim jeszcze przed II wojną światową aż do czasów współczesnych umożliwiły z kolei określenie tempa narastania poszczególnych warstw, czy to niwelacyjnych, czy osadniczych, na przestrzeni wieków. Wykorzystano głównie wyniki badań archeologicznych na głównej osi Ostrowa Tumskiego, ciągnącej się od kościoła Najświętszej Marii Panny przez plac katedralny i katedrę, a więc na osi W-E. Zgeneralizowany przekrój odzwierciedlający narastanie warstw kulturowych przedstawiono na ry- 
cinie 5. Jest to przekrój hipotetyczny, bowiem połączono niewielkie tylko fragmenty przebadanego terenu, ale ma on na celu pokazanie, jak zmieniały się prace związane $\mathrm{z}$ adaptacją tego terenu dla potrzeb mieszkalnych i obronnych i jaka była ich intensywność w różnych okresach istnienia grodu. Intensywność narastania warstw kulturowych była różna $\mathrm{w}$ różnych okresach, jak również przejawiała się inaczej w różnych miejscach. Szerzej omówili ten problem Kaniecki i in. (2012).

W trakcie badań archeologicznych na obszarze wyspy katedralnej stwierdzono ciągłe i intensywne użytkowanie tego terenu przez osadnictwo od VIII/IX w. aż do współczesności, pomimo przejściowych kataklizmów, takich jak: pożary, wojny czy powodzie. Dlatego też w trakcie tych prac odkrywano różnego typu warstwy wewnątrz grodu, od takich, które wyrównywały i podnosiły poziom powierzchni terenu dla potrzeb osadnictwa, szczególnie w obniżeniach, gdzie pomimo podniesienia jego powierzchni cechy podmokłości utrzymywały się jeszcze długo, niekiedy aż do końca XII w., do warstw budowlanych czy śmietniskowych.

Pierwotny charakter powierzchni Ostrowa Tumskiego został więc silnie zmieniony w wyniku działalności gospodarczej człowieka już we wczesnym średniowieczu. W przypadku Ostrowa Tumskiego złożyło się na to przede wszystkim sukcesywne nadsypywanie terenów najniżej usytuowanych $\mathrm{w}$ obrębie grodu, aż powyżej poziomu przeciętnych zalewów powodziowych Warty. Lokalizacja grodu w najniższej części doliny Warty i otoczenie go wałami obronnymi, pełniącymi funkcję wałów przeciwpowodziowych, powodowało podtapianie jego wnętrza w czasie trwania stanów wysokich w Warcie i Cybinie. Stąd od samego początku wykonywano prace związane z podnoszeniem poziomu powierzchni wnętrza grodu. Ślady prac niwelacyjnych zachowały się w przebiegu najstarszych warstw osadniczych, i to zarówno na obszarach niżej, jak i wyżej położonych. Świadczy o tym silne sfałdowanie stropu w przebiegu niektórych warstw oraz zróżnicowanie ich miąższości. Poziom terenu podnoszono stopniowo, najczęściej o kilkadziesiąt centymetrów, chociaż spotykamy również i większe przedsięwzięcia tego typu (Kaniecki 1993). Stosowano też warstwy niwelacyjne, usytuowane poniżej stóp fundamentowych, zarówno palatium książęcego (Dębski, Sikorski 2005), jak i katedry (Józefowiczówna 1963). Stanowiły je konstrukcje drewniane wypełnione piaskiem, niekiedy brukiem kamiennym, mające na celu wzmocnienie nośności tych gruntów. Miąższości tych warstw przekraczały niekiedy 1,5 m.

W trakcie badań archeologicznych natrafiano powyżej rzędnej 54 m n.p.m. na warstwę odzwierciedlającą zniszczenia spowodowane najazdem Brzetysława w 1038/39 r. Przykrywają je warstwy niwelacyjne i osadnicze z XIXIII w., w stropie na ogół zniszczone. Stropowe warstwy tego przekroju, zalegające na rzędnych 56-58 m n.p.m., to warstwy z XVI-XX w., często wymieszane ze sobą, co nie pozwala odtworzyć tempa ich narastania (Dębski, Sikorski 2005, Koćko-Krenz 2005).

W obrębie tych warstw kulturowych występowały również warstwy powodziowe, naniesione przez Wartę i pochodzące $z$ rozmycia zniszczonego wału obronnego. Szczególnie wyraźnie zaznaczyły się w przebiegu warstw ślady powodzi z $1253 \mathrm{r}$. w postaci nanosów rzecznych i piasku pochodzącego $\mathrm{z}$ rozmycia wału obronnego, na które natrafiano na różnych stanowiskach badawczych.

Podmokłość niektórych części obszaru Ostrowa Tumskiego utrzymywała się jednak długo. Badania wykaza-

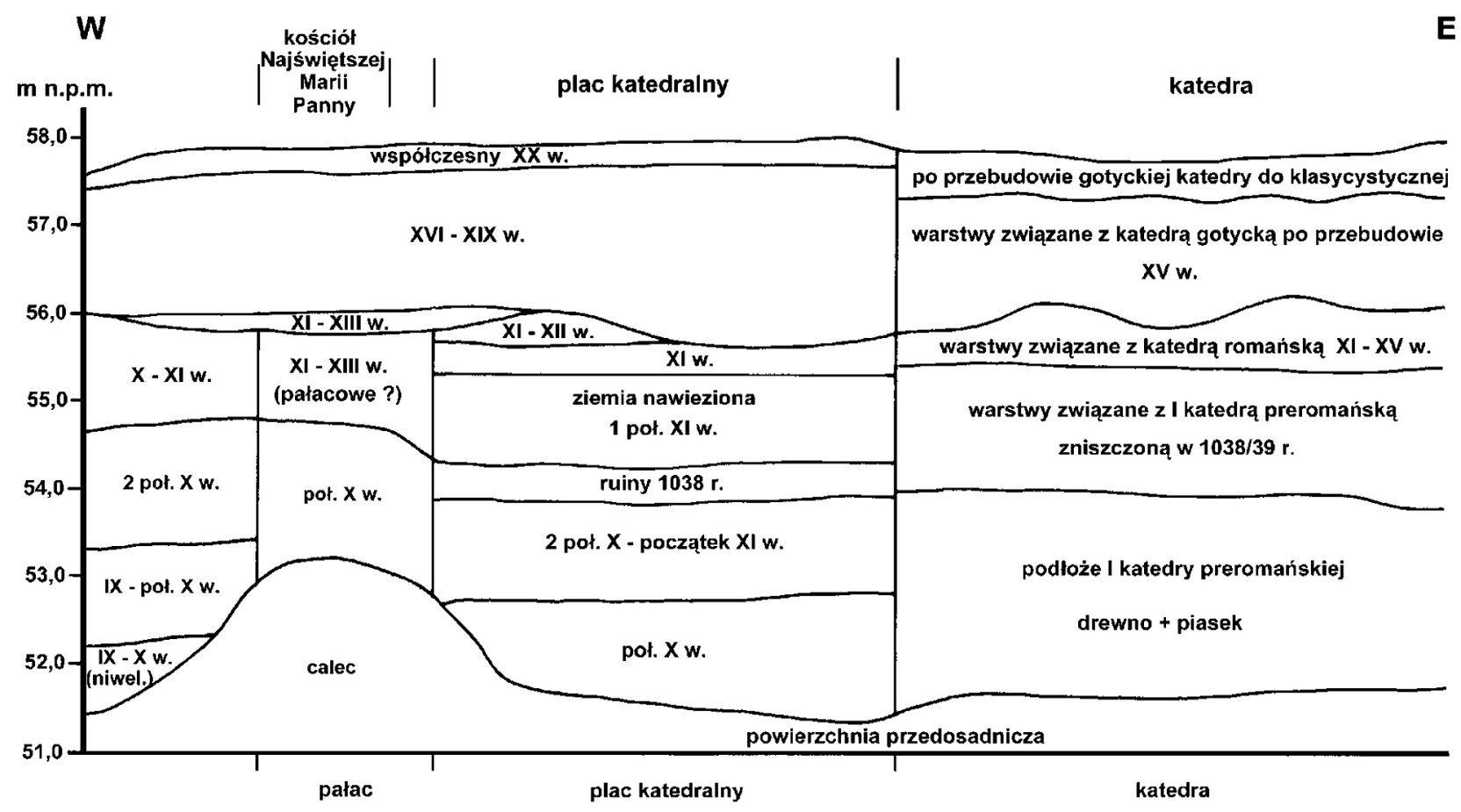

Ryc. 5. Przekrój określający narastanie warstw kulturowych na Ostrowie Tumskim

Fig. 5. A section setting out the build-up of layers of cultural changes at the Ostrów Tumski 
ły, że były to tereny silnie podmokłe aż do końca XII w. i przez cały ten czas sukcesywnie podnoszono ich poziom, układając kolejno coraz to nowe warstwy nasypu ziemnego, faszyny, płaty plecionki i chaotycznie rozrzucane gałęzie oraz gałązki. Miejscami na plecionce występowały kamienie polne o średnicy około $20 \mathrm{~cm}$. Pomimo sukcesywnego nadsypywania powierzchni, warstwy aż do rzędnej 53,30 m n.p.m. wskazywały na dużą podmokłość tego terenu. Dopiero warstwy wyżej leżące, a więc datowane na przełom XII i XIII w., nie wykazują cech podmokłości (Malinowska 1961). Ta podmokłość niektórych części Ostrowa Tumskiego zaznaczyła się nie tylko w przebiegu warstw zawierających szczątki konstrukcji drewnianych, podnoszacych poziom terenu, ale również w składzie gatunkowym mięczaków. Dominowały wśród nich bowiem gatunki typowe dla małych zbiorników wodnych i wilgotnych siedlisk lądowych (Klichowska 1961). Interesujący jest fakt, że tak długie, bo utrzymujące się ponad 200 lat (od połowy X do końca XII w.), silne uwilgotnienie badanego terenu, pomimo sukcesywnego podnoszenia jego powierzchni o ponad $1,5 \mathrm{~m}$, wskazuje przede wszystkim na podnoszenie się poziomu wody w korytach Warty i Cybiny. Przypuszczalnie wiązało się to ze wzrostem uwilgotnienia klimatu, co miało wtedy miejsce (Kaniecki 1993).

W świetle przedstawionych badań archeologicznych, przeprowadzonych w obrębie Ostrowa Tumskiego można stwierdzić, że do połowy XIII w., w wyniku stałego podnoszenia powierzchni terenu poprzez stosowanie nasypów i tworzenia się warstw osadniczych, jego poziom wzrósł w ciągu 300 lat od 3 do 5,5 m, a więc do rzędnej około 56 m n.p.m. Dominowały jednak, szczególnie w pierwszym okresie istnienia grodu, prace związane z przystosowaniem powierzchni grodu dla potrzeb osadnictwa.

W połowie XIII w. dalszy rozwój terytorialny grodu na Ostrowie Tumskim został zahamowany, głównie z braku miejsca na dalszą rozbudowę. Gród od południa i północy otoczony podmokłymi łąkami terasy zalewowej Warty i jej rozlewiskami, od zachodu ograniczony odnogą Warty, nazywaną Starą Rzeką, a od wschodu Cybiną, nie miał większych możliwości rozbudowy w obrębie tej terasy. Powiększenie grodu np. w kierunku północnym wiązałoby się z nadsypaniem nowo włączonej powierzchni o 4-5 m, co chyba przekraczało możliwości jego mieszkańców. W tej sytuacji książę Przemysł I zdecydował się przenieść ośrodek gospodarczy miasta na lewy brzeg Warty, na terasę nadzalewową (II). W 1252 r. książę w zamian za Ostrów Tumski przejął część gruntów na lewym brzegu Warty, przy kościołach św. Wojciecha i św. Marcina należących do biskupa, w sąsiedztwie miejsca przeprawy przez Wartę. W 1253 r. zakończono prace lokacyjne nowego miasta na lewym brzegu Warty i odtąd Poznań rozwijał się głównie na lewym brzegu rzeki w obrębie terasy nadzalewowej (II), wznoszącej się od 3 do $5 \mathrm{~m}$ ponad poziom wody w korycie Warty.

Obecna powierzchnia Ostrowa Tumskiego w rejonie katedry mieści się w przedziale 57,5-58,0 m n.p.m. Jednak układ warstw kulturowych w przedziale 56,0-58,0 m n.p.m. uległ zniszczeniu w wyniku rozlicznych prac budowlanych, nasypowo-niwelacyjnych czy też w trakcie wcześniej prowadzonych prac badawczych. Często brakuje w tych warstwach materiału, który można by wiązać z konkretnym przedziałem czasowym.

W świetle przedstawionych wyników badań ocenić można, jak wielki wysiłek musieli podjąć mieszkańcy grodu na Ostrowie Tumskim już w najwcześniejszym okresie jego istnienia, a więc do połowy XIII w., aby przystosować teren do swoich potrzeb. Prace te obejmowały budowę obwałowań, które nie tylko pełniły funkcje obronne, ale chroniły również wnętrze grodu przed zalewami wodami Warty i Cybiny w czasie wezbrań. Jednak w wyniku wzrostu uwilgotnienia klimatu w wiekach XIXII rzeki te podnosiły poziom swych wód, co wymagało sukcesywnego nadsypywania powierzchni terenu wewnątrz grodu, niekiedy nawet o 4-5 m.

W procesie przemian struktury krajobrazowej do połowy XIII w. szczególnie silnie zaznaczały się zmiany krajobrazu naturalnego (ukształtowania powierzchni terenu, stosunków wodnych), i to one w dużym stopniu determinowały zmiany krajobrazu kulturowego (np. możliwości zabudowy). W następnym okresie w miarę postępu technologii i coraz większego uniezależniania się człowieka od środowiska przyrodniczego zmiany krajobrazu kulturowego były coraz wyraźniejsze.

Z kolei obszar terasy II, na której założono lewobrzeżny Poznań, również wskutek narastania warstw kulturowych osiągnął już około 1536 r., a więc do czasu wielkiego pożaru miasta, poziom około $58 \mathrm{~m}$ n.p.m., a więc rzędną III poziomu terasowego i sztucznie podniesionej terasy zalewowej na Ostrowie Tumskim. Od tego okresu bruki na Starym Rynku utrzymywane są na tym samym poziomie, tzn. narastające sukcesywnie warstwy gruntów kulturowych są systematycznie usuwane. Jednak pierwotny poziom określały rzędne od 54 do $57 \mathrm{~m}$ n.p.m. Terasa II, zbudowana $z$ piasków zalegających na żwirach, charakteryzuje się powierzchnią prawie równą, lekko nachyloną w kierunku osi doliny. Tworzyła ona zwartą, słabo rozczłonkowaną formę, ograniczoną stokiem doliny, korytem Warty od wschodu oraz terasą zalewową, podtopioną od południa i północy. W obrębie terasy nadzalewowej (II) warunki dla osadnictwa były korzystne. Obszar ten znajdował się powyżej zasięgu przeciętnych fal wezbraniowych, grunty budowlane były dobre, bowiem dominowały utwory piaszczyste, a woda gruntowa występowała na głębokości od 2 do 4 m p.p.t.

Początkowy okres istnienia Poznania lewobrzeżnego, a więc od połowy XIII do końca XIV w., charakteryzował się stosunkowo słabym rozwojem. Poznań był wtedy miastem peryferyjnym, leżącym poza głównymi szlakami handlowymi. W pierwszym okresie dokonano przełożenia cieków, tj. Bogdanki i odnogi Warty zwanej Notecią, do fos oraz wyrównywano powierzchnię terenu wewnątrz miasta. Zabudowa obejmowała wtedy głównie obszar ograniczony murami miejskimi, wybudowanymi około 1280 r. Niwelacja 
terenu miejskiego polegała przede wszystkim na zasypaniu obniżeń wypełnionych osadami organicznymi i zastoiskowymi. Ich obecność stwierdzono w sąsiedztwie ratusza, pałacu Górków, wzdłuż północnej pierzei Rynku oraz wzdłuż zachodniego zbocza doliny Warty, gdzie ciągnęły się wąskim pasem.

Lokując Poznań na terasie II (nadzalewowej), przylegającej do głównego koryta Warty, o powierzchni pierwotnej 54,5-55,0 m n.p.m. i dodatkowo zabezpieczonej przez zaadaptowaną dla potrzeb obronnych sieć rzeczną oraz przez bagna od północy, odrzucano korzyści wynikające z zajęcia obszaru położonego wyżej, np. na terasie wysokiej Warty lub na wysoczyźnie. Zadecydowały względy obronne. Poznań lewobrzeżny zajmował wtedy 21 ha i był trzecim co do wielkości zajmowanego obszaru miastem w Królestwie Polskim. Na terenie miejskim, w obrębie wydzielonych parcel, dominowała zabudowa typu wiejskiego obejmująca drewniane budynki mieszkalne i gospodarcze, a przestrzenie pomiędzy nimi wykorzystywano jako ogrody. Wraz ze wzrostem zaludnienia miasta następowały podziały pierwotnych parcel i zaczęła wzrastać wysokość stawianych domów. Była to jednak zabudowa drewniana, niszczona przez częste pożary.

Okres rozkwitu Poznania rozpoczął się pod koniec XIV w., kiedy to w wyniku unii polsko-litewskiej miasto znalazło się na ruchliwym szlaku handlowym, łączącym zachodnią Europę i północne Włochy, poprzez środkowe Niemcy z Brześciem, Wilnem i Moskwą. Długie lata spokoju i brak zagrożenia zewnętrznego sprawiły, że osadnictwo stopniowo obejmowało tereny piaszczyste, przyległe od wschodu i południa do miasta. Od XV w. zaczęto również zasiedlać wzdłuż grobli komunikacyjnych przerzuconych przez dolinę Warty, fragmenty terasy najniższej, tj. wyspy: Chwaliszewską i Nową Groblę. Powstałe tam osady otrzymały w połowie XV w. prawa miejskie. W XVI i w pierwszej połowie XVII w. zabudowa zaczęła obejmować łagodniejsze stoki doliny Warty oraz skrajną część obszaru terasy górnej i wysoczyznowej. Jednocześnie ponownie zasiedlano tereny położone na prawym brzegu Warty. Jak wynika ze sztychu Brauna i Hogenberga (1618 r.), Poznań otoczony był wieńcem przedmieść. W okresie rozkwitu miasto zamieszkiwało ponad 20000 mieszkańców, a zabudowane tereny obejmowały 340 ha. Odpowiednio przystosowana sieć wodna wzmacniała obronność miasta, ale nie jego przedmieść. Okres ten charakteryzował się nasileniem prac zmieniających organizację sieci wodnej, zarówno dla celów obronnych, jak i wykorzystania energii wód płynących dla potrzeb takich gałęzi przemysłu, jak młynarstwo i garbarstwo. Zaczęto ingerować w naturalne systemy hydrograficzne, wstrzymując płynięcie wody bądź kierując ją za pomocą przegród do odnóg, nad którymi stały młyny wodne. Koryto Warty przegradzały groble zwane ,gaciami”: Kamienna i Spustna w południowej części miasta w pobliżu mostu Wiel- kiego (Łacina) oraz trzecia w pobliżu klasztoru dominikanów (Kaniecki 1993). Piętrzenie wód i tworzenie stawów na terenach miejskich i podmiejskich celem zabezpieczenia ciągłej pracy młynów wodnych powodowało podniesienie poziomu płytkich wód podziemnych na terenach przyległych. Nałożył się na to kolejny wzrost uwilgotnienia klimatu. Przejawił się on zwiększonym nawodnieniem dolin rzecznych i wzrostem nierównomierności przepływów w ciekach. Efektem było jak gdyby względne obniżenie terasy nadzalewowej, na której zbudowano Poznań lewobrzeżny, i częste zalewy powodziowe miasta. Podnoszeniu się poziomu wód powierzchniowych i podziemnych towarzyszył proces tworzenia się i utrzymywania obszarów podmokłych, szczególnie w sąsiedztwie miasta. W jego obrębie strefy podmokłe były prawdopodobnie względnie szybko likwidowane poprzez zasypanie. Sytuacja taka utrzymywała się praktycznie do końca XVIII w.

Wiek XVII, szczególnie po wojnie ze Szwecją w 1655 r., przyniósł zniszczenie i upadek gospodarczy miasta. Dalsze działania wojenne oraz klęski żywiołowe (powodzie, huragan, pożary i epidemie dżumy) doprowadziły miasto do ruiny. Liczba ludności zmalała do około 5000, likwidacji uległy niektóre przedmieścia, wyludnione zostały wsie miejskie. Brak środków na odbudowę bądź wzmocnienie fortyfikacji, zarówno murów, szańców, jak i fos, ułatwił wojskom nieprzyjacielskim kilkakrotne zdobycie miasta i grabieże. Na zły stan murów obronnych i fos wskazują również lustracje miejskie z XVIII w. Cechą charakterystyczną tego okresu jest rozbudowa fortyfikacji ziemnych, zwłaszcza u wylotu bram miejskich. Już w 1655 r. Szwedzi okupujący Poznań usypali szańce ziemne w miejscach newralgicznych na przedpolu murów miejskich. Zmieniały one wyraźnie rzeźbę terenu przyległego do miasta. Można to łatwo zobaczyć na widoku Poznania w czasie oblężenia w 1704 r. z dzieła ,Stragona albo stołeczne miasto Poznań", znajdującego się w zbiorach Biblioteki Kórnickiej (Kaniecki 1993). Szczególnie imponująco wyglądały wtedy bastiony: Garbarski i usytuowany przed bramą Wrocławską. W latach następnych, aż do połowy lat 30 . XVIII w., utrzymywano te umocnienia ziemne na przedpolu miasta. Później powodzie, występujące wtedy często, powodowały systematyczne niszczenie urządzeń obronnych, zwłaszcza tych usytuowanych nad Wartą. Rozmywane i rozkopywane, przyczyniły się jednak do wyraźnego podniesienia poziomu terenu na przedpolu historycznego miasta. W okresie upadku gospodarczego miasta, co miało miejsce szczególnie w XVIII stuleciu, nie podejmowano na większą skalę prac zabezpieczających koryta Warty i jej odnóg, co doprowadziło do zdziczenia rzeki. $\mathrm{Z}$ upadku gospodarczego miasto zaczęło się dźwigać dopiero w drugiej połowie XVIII w., w czasie działania Komisji Dobrego Porządku, dzięki której zwiększyły się dochody miasta, uporządkowa- 
no teren miejski i przyległy i rozpoczęto odbudowę centrum miasta oraz urządzeń komunalnych. Pod koniec XVIII w. Poznań pozostawał jednak stosunkowo niewielkim miastem z liczbą mieszkańców około 13000 , co stawiało go na szóstym miejscu wśród miast Królestwa Polskiego. Miasto obejmowało obszar zamknięty murami miejskimi, których obwód wynosił 2300 kroków. Dalszemu rozwojowi Poznania przeszkodziło wcielenie go, wraz z częścią Wielkopolski, do Prus w wyniku II rozbioru Polski.

Pod zaborem pruskim, tj. od 1793 r., nastąpił znaczny rozwój terytorialny miasta $\mathrm{w}$ wyniku przyłączenia ponad dziesięciu osad podmiejskich, w tym i tych znajdujących się na prawym brzegu Warty. Jednak w 1817 r. zapadła decyzja, aby przekształcić Poznań w twierdzę. Od 1828 r. rozpoczęto prace fortyfikacyjne, które zakończono w latach siedemdziesiątych XIX stulecia. Miasto na powrót zostało zamknięte pierścieniem murów obronnych i fos. Jego obwód liczył wówczas tylko $6 \mathrm{~km}$. Znacznie wzrosła liczba mieszkańców, od około 18000 w 1816 r. do około $66000 \mathrm{w} 1890$ r. Jednak istniejące wówczas fortyfikacje stanowiły zaporę uniemożliwiającą przestrzenny rozwój miasta. Na Wzgórzu Winiarskim powstała wielka cytadela, a w pierścieniu obronnym - warownie i fosy oraz śluzy. Powierzchnia obszaru miejskiego w obrębie wałów fortecznych wynosiła

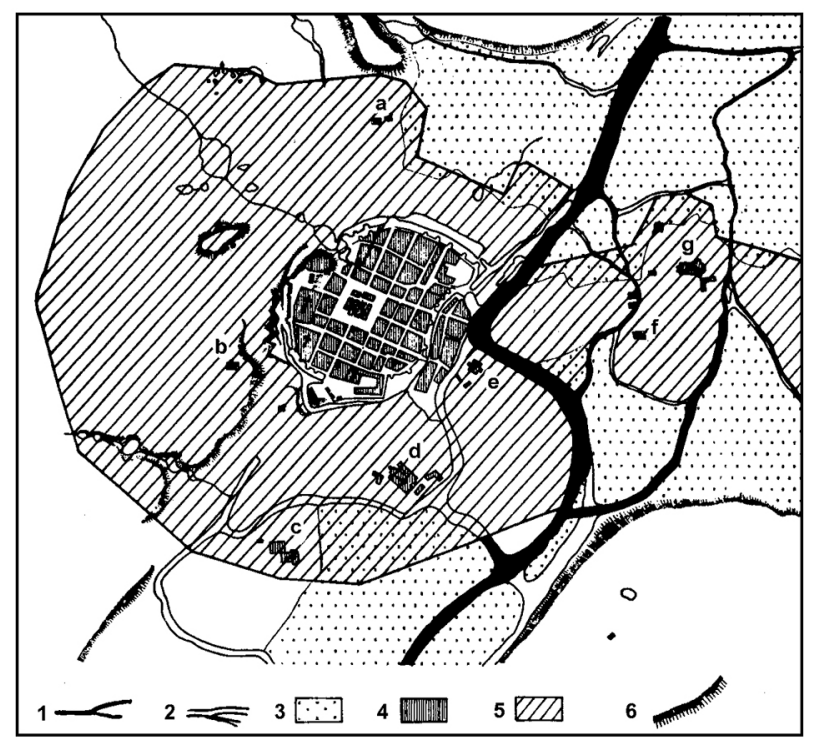

Ryc. 6. Zasięg twierdzy pruskiej na tle dawnego Poznania w drugiej połowie XIX w.

1 - cieki zachowane, 2 - cieki zlikwidowane, 3 - obszary podmokłe, 4 - dawne strefy zabudowane i obiekty, 5 - strefa zabudowy w XIX w., 6 - stoki

Kościoły: a - św. Wojciecha, b - św. Marcina, c - Karmelitów od Bożego Ciała, d - Bernardynów, e - Wszystkich Świętych, f - św. Mikołaja, $\mathrm{g}$ - katedra

Fig. 6. The space of the Prussian fortress against the background of the old Poznan in the 2nd half of the 19th century

1 - active streams, 2 - dismiss streams, 3 - wetlands, 4 - ancient built-up areas and objects, 5 - built-up area in 19th century, 6 - slopes

Churches: a - Saint Wojciech, b-Saint Martin, c - Carmelites, d - Bernardine Fathers, e - All Saints, f - Saint Nicolaus, $g$ - cathedral tylko 776,4 ha (Nowakowski 1929), z czego jedynie około 50 ha stanowiły tereny budowlane (Wojtkowski 1929). Optymalne wykorzystanie gruntów wewnątrz murów miejskich, przy wzrastającej liczbie ludności, wymuszało więc tworzenie nowych terenów budowlanych w obrębie miasta (ryc. 6). Zasypano strumienie, łąki, stare fosy i tereny podmokłe. Na niektórych obszarach, np. na dawnych Groffowych Łąkach przylegających od wschodu do Wzgórza św. Wojciecha, miąższość nasypów przekraczała 5 , a nawet $10 \mathrm{~m}$. $\mathrm{Na}$ tych nowo pozyskanych terenach wznoszono początkowo zabudowę niską, a dopiero po pewnym czasie zabudowę wysoką. Najpierw na tych obszarach, dawniej podmokłych, zasiedlano strefy przyległe do nasypów drogowych, a następnie strefy te rozszerzano, np. wzdłuż ul. Tama Garbarska (obecnie ul. Garbary do ul. Szelągowskiej). W 1892 r. na Groffowych Łąkach, o powierzchni 5,7 ha, postanowiono wybudować rzeźnię miejską wraz z targowiskiem dla zwierząt, w związku z czym teren podmokłych łąk podwyższono nasypem o miąższości rzędu 3-5 $\mathrm{m}$. Ziemię zwożono z okolic dzisiejszych ulic: Wołyńskiej, Szydłowskiej i Obornickiej.

W okresie tym nastapiło zniszczenie naturalnych warunków fizjograficznych wewnątrz murów miejskich. Wiązało się to z zasypaniem strumieni, łąk i terenów podmokłych oraz starych fos celem pozyskania nowych terenów budowlanych. Nastąpiła zmiana hipsometrii obszaru miejskiego. Ponadto wprowadzono do sieci kanalizacyjnej niektóre cieki, np. odnogi Warty - Kamionkę i Zgniłą Wartę, dolny bieg Bogdanki i Wierzbak. Powstały też liczne zbiorniki wodne na terenach podmiejskich, będące wyrobiskami po glinie zwałowej, iłach warwowych i piasku. Ponadto wykonano prace regulacyjne koryta Warty, co doprowadziło do jego ustabilizowania się.

W dniu 3.09.1902 r. cesarz Wilhelm osobnym dekretem wydał zezwolenie na zburzenie fortyfikacji i obwałowań miasta. Poznań stał się na powrót miastem otwartym, w związku z czym powstały korzystne warunki dla jego rozwoju przestrzennego. Trwa on do dzisiaj. Rozbudowa miasta postępowała głównie w kierunku zachodnim i południowym, obejmując przede wszystkim teren wysoczyznowy. Przejawem wzrostu zabudowy obszaru miejskiego jest obecność licznych i dużych stawów powyrobiskowych w rejonie Górczyna i Starołęki. Jeszcze przed I wojną światową zniesiono zachodni pierścień umocnień, likwidując forty i warownie oraz zasypano fosy. Uzyskano w ten sposób 121 ha terenów budowlanych. Z kolei likwidacja fortyfikacji wodnych umożliwiła osuszenie terenów podmokłych na ich przedpolu i częściową zabudowę. Rozpoczął się również proces osuszania znacznych obszarów podmokłych przyległych do miasta od strony południowej, a więc Łęgów Wildeckich i Dębińskich. Ponadto nadsypano o 2-4 m powierzchnie terenu, szczególnie na Łęgach Wildeckich, stosując nasypy uzyskane z rozbiórki 
fortów. Kolejką wąskotorową przywożono na te tereny piasek z okolic Dębiny i Lubonia (Nowakowski 1929). W 1901 r., po wielkich powodziach w latach 1888 i 1889 , zaczęto budować wały przeciwpowodziowe w rejonie śródmieścia, Chwaliszewa i Ostrowa Tumskiego. Korona wałów sięgała rzędnej 58,166 m n.p.m. W 1889 r. obniżono tzw. ,tamę berdychowską", ułatwiając spływ wysokich wód Warty do nowo zbudowanych koryt ulgi I i II. W 1900 r. podniesiono również o $1 \mathrm{~m}$ poziom Chwaliszewa (Kaniecki 1993). W latach 1901-1905 wybudowano między mostem Chwaliszewskim a mostem kolejowym na Garbarach port rzeczny z sześćsetmetrowym pionowym nabrzeżem przeładunkowym. Zainicjowano również prace wiążące się z projektem regulacji biegu Warty w Poznaniu, którego autorem był S. Schultz.

Po odzyskaniu niepodległości w 1918 r., zmieniły się koncepcje dalszego rozwoju przestrzennego miasta. Przyłączono m.in. osady prawobrzeżne i zaczęto tam lokalizować nowe zakłady przemysłowe. Podjęto prace odwodnieniowe i kontynuowano prace rozbiórkowe przy dawnych fortach twierdzy pruskiej oraz zapoczątkowane jeszcze przed wojną prace ziemne w dolinie Warty, szczególnie na Łęgach Wildeckich. Po wielkiej powodzi w 1924 r. kontynuowano prace związane z budową wałów przeciwpowodziowych na dalszych odcinkach od miasta.

Według szacunków Nowakowskiego (1929) tylko w dziesięcioleciu 1919-1928 przekopano i przewieziono około $2,5 \mathrm{mln} \mathrm{m}^{3}$ ziemi, głównie w dolinie Warty, podnosząc znacznie poziom terasy zalewowej.

W czasie II wojny światowej, poprzez spiętrzenie wód Bogdanki, został utworzony zbiornik retencyjny Rusałka. Rozpoczęto też prace nad budową zbiornika retencyjnego Malta oraz nowego koryta Warty w obrębie śródmieścia. Po II wojnie światowej obserwuje się nadal ciągły, przestrzenny rozwój miasta i przyłączanie coraz to nowych obszarów. Dominują na nich prace odwodnieniowe, chociaż wybudowano duży zbiornik wodny - Jezioro Maltańskie. Zanikowi ulega sieć rzeczna, szczególnie tych drobnych cieków, wprowadzona albo do układu kanalizacyjnego, albo po prostu zasypana. Na obszarze Poznania występuje ponad 150 sztucznych zbiorników wodnych, powyrobiskowych, rekreacyjnych, infiltracyjnych itp. Obecna powierzchnia najstarszych części miasta, np. Starego Miasta, jest mało zróżnicowana pod względem hipsometrycznym. Natomiast zmienność miąższości nasypów w jego obrębie wskazuje, jak wielkim uległa przeobrażeniom powierzchnia pierwotna, a w związku z tym sieć cieków i stosunki wodne (Kaniecki 1993).

\section{Podsumowanie}

W artykule przedstawiono próbę określenia kierunku i zakresu przemian środowiskowych w dolinie Warty w Poznaniu, wiążących się z antropopresją w ciągu 1000 lat istnienia miasta. Pierwotna jego lokalizacja obejmowała najniższą część doliny Warty, tj. terasę zalewową, chronioną przez małą rzeczkę Cybinę i odnogę Warty. Teren ten adaptowano pod zabudowę, podnosząc jego poziom poprzez ciągłe jego nadsypywanie. Następna lokalizacja objęła obszar terasy nadzalewowej (II), której poziom również stopniowo nadsypywano. Dopiero w XIX i XX w. miasto objęło zwartą zabudową terasy wyższe i wysoczyznę po obu stronach doliny Warty.

W związku z takim kierunkiem rozwoju stwierdza się różne tendencje i rodzaje prac nad dostosowaniem warunków fizjograficznych do potrzeb jego mieszkańców. Najwięcej działań dotyczyło przekształcenia hipsometrii obszaru miasta oraz stosunków wodnych i układu sieci hydrograficznej. Zmiany te miały zarówno charakter ciągły o różnym nasileniu $\mathrm{w}$ różnych okresach istnienia miasta, jak i skokowy, związany np. z budową fortyfikacji ziemnych okalających miasto, co miało miejsce w okresie X-XIII i XVIII w. Grunty nasypowe podnoszące poziom terenu nie są jednorodne, lecz składają się na ogół $z$ różnych warstw o odmiennej teksturze i genezie. Również układ sieci rzecznej w sąsiedztwie miasta był ciągle zmieniany dla potrzeb obronnych (fosy) i energetycznych (młyny wodne). Brzegi koryt, zarówno Warty, jak i jej dopływów, umacniano bądź nawet korygowano ich przebieg. Na odcinkach niechronionych natomiast Warta zmieniała dość często swój bieg, tworząc nowe odnogi, zakola i starorzecza.

Problem zmian środowiskowych obszaru dolin rzecznych w obrębie miast jest typowym problemem interdyscyplinarnym, w którego opracowaniu, poza przedstawicielami nauk przyrodniczych (geografowie, geolodzy, biolodzy), powinni wziąć również udział historycy i archeolodzy.

\section{Literatura}

Callier E., 1887. Poznań. W: B. Chlebowski (red.), Słownik geograficzny Królestwa Polskiego. T. VIII. Warszawa.

Dębski A., Sikorski A., 2005. Ostrów Tumski 10 - charakterystyka warstw i materiałów źródłowych w wykopie XXIV. W: H. Kóćka-Krenz (red.), Poznań we wczesnym średniowieczu. T. IV, Poznań.

Józefowiczówna K., 1963. Z badań nad architekturą przedromańską i romańską w Poznaniu. IHKM, PAN, Ossolineum, Wrocław.

Kaniecki A., 1993. Poznań. Dzieje miasta wodą pisane. Cz. I. Przemiany rzeźby i sieci wodnej. Wydawnictwo „Aquarius”, Poznań.

Kaniecki A., 2004. Poznań. Dzieje miasta wodą pisane. Cz. I-III. Wydawnictwo Poznańskiego Towarzystwa Przyjaciół Nauk, Poznań.

Kaniecki A., Stryjakiewicz T., Sosiński P., 2012. Zmiany krajobrazu, zagospodarowania przestrzennego i funkcji Ostrowa Tumskiego. Dziedzictwo kulturowe Ostrowa Tumskiego w Poznaniu. Podręcznik dla nauczycieli i edukatorów. Centrum Turystyki Kulturowej TRAKT, Poznań. Online - www.poznan.pl/trakt.

Klichowska M., 1961. Materiały zoologiczne ze stanowiska Ostrów Tumski 17 w Poznaniu (1953-1954). W: W. Hensel (red.), Poznań we wczesnym średniowieczu. T. III. Ossolineum, Wrocław.

Koćko-Krenz H., 2005. Zarys stanu badań Instytutu Prahistorii UAM na Ostrowie Tumskim w Poznaniu w latach 1999-2004. Badania na posesjach Ostrów Tumski 9 i 10. W: H. Kóćka-Krenz (red.), Poznań we wczesnym średniowieczu. T. V. Poznań.

Łukaszewicz J., 1838. Obraz historyczno-statystyczny miasta Poznania w dawniejszych czasach. T. I-II. Poznań. 
Malinowska M., 1961. Badania na Ostrowie Tumskim 17 w Poznaniu w latach 1953-1954. W: W. Hensel (red.), Poznań we wczesnym średniowieczu. T. III. Ossolineum, Wrocław.

Niesiołowska A., Perzyńska M., Żak J., 1960. Badania na posesji Ostrów Tumski 13 w latach 1950-1953. W: W. Hensel (red.), Poznań we wczesnym średniowieczu. T. II. Ossolineum, Wrocław.

Nowacki J., 1959-1964. Dzieje archidiecezji poznańskiej. T. I-II. Poznań.

Nowakowski M., 1929. Budowa i utrzymanie ulic, placów i dróg miejskich. Księga Pamiątkowa Miasta Poznania, Poznań.
Rogalanka A., Ruszczyńska T., 1978. Zródła kartograficzne do dziejów Poznania. Katalog wystawy. Poznań.

Warschauer A., 1892. Stadtbuch von Posen. T. I-II. Posen.

Wojtkowski A., 1929. Poznań od roku 1793 do 1853. Księga Pamiątkowa Miasta Poznania, Poznań.

Żak J., 1959. Badania w ogrodzie przy ul. Ostrów Tumski 10 w 1946 roku. W: W. Hensel (red.), Poznań we wczesnym średniowieczu. T. I, Warszawa. 